\title{
The Social and Ecological Impact of 'Pro-Alcool'
}

\section{Ignacy Sachs \\ Dalia Maimom \\ Mauricio Tiomno Tolmasquim}

Brazil's National Alcohol Programme ('Pro-Alcool'), celebrated its tenth anniversary in November 1985, amid intense controversy over its costs and results. Launched as a response to the 1973 oil shock, it is the largest biomass liquid fuel programme in the world.

The quantitative record achieved in the short span of ten years is impressive. Fifty billion litres of anhydrous and hydrated alcohol were produced and 560 new distilleries built or approved in addition to the 33 existing at the beginning of the programme. By 1978 , 1.5 bn litres of anhydrous alcohol had been added to gasoline. In 1979, after the second oil shock, the government set a target of 10.7 bn litres for the agricultural year 1985/86, which was more than fulfilled. In 1985, about 400 operating plants, with a capacity to turn out up to 15 bn litres per year (Exame, 27 November 1985), produced 11 bn litres, out of which 7.63 bn were used as an additive to gasoline (anhydrous alcohol) and as a substitute for gasoline in 100 per cent alcohol powered cars (hydrated alcohol).

Table 1 shows the impact of the second and much discussed phase of 'Pro-Alcool', shifting the emphasis from the production of anhydrous alcohol to that of hydrated alcohol, linked with the production of alcohol-powered cars. While the consumption of anhydrous alcohol somewhat decreased, that of hydrated alcohol, practically non-existent in 1979, accounts today for almost three quarters of total consumption. There were $2.5 \mathrm{mn}$ alcohol-powered cars in 1985 (out of a total $12 \mathrm{mn}$ ). They account now for more than 90 per cent of the output of motor-car factories, which expect to sell more than 900,000 units on the internal market in 1986. The success of 'ProAlcool' is one of the principal reasons for the sharp decrease in the consumption of gasoline: 46.44 per cent less in 1985 than in 1979.

Current production of alcohol for fuel substitutes is about 150,000 barrels of oil per day. It should be noted, however, that over the same ten years Petrobras managed to increase the domestic output of oil from 170,000 barrels/day to over $600,000 \mathrm{~b} / \mathrm{d}$, probably at a lesser investment per unit of capacity added. It is true however, that much greater uncertainty was attached to offshore oil exploration than to the expansion of the alcohol distilleries, and even to the transformation of the motor-car industry. The technology of alcohol extraction has no secrets for the Brazilians and, even before 'Pro-Alcool', sugar plants were producing about $500 \mathrm{mn}$ litres of alcohol a year from molasses remaining after sugar was processed. The first phase of 'Pro-Alcool' thus consisted in using idle capacities in the existing distilleries and in attaching a few new ones to the sugar plants. In this way 'Pro-Alcool' had the flexibility desired by the sugar producers, as the quantity of anhydrous alcohol added to gasoline could be adjusted to the vicissitudes international sugar market (see Table 2).

In contrast, the second phase introduced a rigidity welcomed by independent alcohol producers and motor-car manufacturers. The former are certain now to keep a captive market for their hydrated alcohol, what ever the cost and price differential with respect to gasoline, in the form of the demand for fuel from the rapidly growing fleet of alcohol-powered cars. The latter, by persuading the Brazilian Government to accept the shift to alcohol-powered cars with ambitious production targets, avoided the danger of seeing their outlets shrinking because of a possible rationing of gasoline, or because of a major policy turn, advocated by many, aimed at giving higher priority to mass transit systems in the towns and to electrified railways for inter-city transport. ${ }^{1}$

Opinions diverge widely about the investment outlays disbursed to build up present alcohol production capacity and the total amount of subsidies offered by the Government. Official sources put the cost of 'ProAlcool" at $\$ 6-8$ bn and claim that the import substitution effect so far amounts to $\$ 7.3 \mathrm{bn}$. Independent researchers arrive at much higher cost figures: more than $\$ 10$ bn [Pelin, quoted in Exame 1985] and even $\$ 20$ bn including foregone taxes (from which alcohol producers are exempted) [Senhor, 4 March 1986]. This puts the cost in the range of $\$ 1,000-3,000$ per tonne of oil equivalent (TOE) of installed capacity, most of it paid for by the Government. In the first phase of the programme, BNDES (The National Bank for Economic and Social Development) went as far as to offer 12 year loans, with a three-year grace period and a 15 per cent interest rate at a time when inflation was running at 40 to 80 per cent per year [Batista 1984]. Such loans could cover 80 or even 90 per cent of the total value of

I See in particular Homem de Melo and Pelin (1981). The reduced flexibility of the second phase of 'Pro-Alcool' has been strongly criticised e.g. by Barzelay and Pearson (1985). 
planned investment (often overvalued for the purpose of loan taking). The conditions were modified between 1980 and 1983, but still remained very generous: a three to six per cent rate of interest plus indexation covering 40 to 50 per cent of the inflation rate measured by the value of government bonds. Even by Latin-American standards, giving away this amount of public resources to private enterprise was exceptional. No wonder that sugar-cane planters, sugar and alcohol producers, private bankers and motor-car manufacturers joined ranks to create a very strong lobby of enthusiastic supporters of 'Pro-Alcool'.

An even broader range of figures is offered as estimates of the production costs of alcohol. In 1983, Homem de Melo and Pelin estimated the social cost of one barrel of oil equivalent (BOE) at $\$ 71$ for anhydrous alcohol and $\$ 79$ for hydrated alcohol, compared with $\$ 38$ per barrel for gasoline. Official sources, as was to be expected, arrive at much lower estimates and, furthermore, point to the possibility of cutting costs by 20 per cent, both by improving the yields per hectare of sugar cane and the quantity of alcohol extracted from each tonne of sugar cane. Petrobras sources put the cost of one BOE at $\$ 40$ while the Minister of Mines, quoting figures prepared by COPERSUGAR (Central Cooperative of Sugar and Alcohol Producers) went so far as to affirm that alcohol was competitive with oil priced at $\$ 29$ per barrel [Gazeta Mercantil, 4 June 1986].

At any rate, with the present very low prices of oil, alcohol is far off the mark, even taking, on face value, the most favourable (and unlikely) estimates. Two qualifications should be made, however.

The estimates of the social cost of production of alcohol are very sensitive to the choice of the shadow price of the dollar. Sensitivity tests, using different shadow prices for foreign exchange, have not, to our knowledge, been conducted by the authors of various studies. Much depends on the judgment attached to the opportunity cost of the foreign exchange saved, the importance of reducing the country's dependence on oil imports, as well as on the comparative costs of reducing this dependence by investing in alternative energy sources, primarily domestic oil production. In their important study of the import-substituting capacity created in Brazil as a response to the 1973 oil shock, Barros de Castro and Pires de Souza (1985) unfortunately do not break down the figures arrived at for oil substitution, nor do they discuss the costs. ${ }^{2}$

The above figures do not include the cost of distribution of alcohol through the immense territory. The number of selling points (service stations) is

\footnotetext{
2 In 1984, the import subst ituting effect for oil is evaluated by them at $\$ 4.4$ bn to be compared with $\$ 2.99$ bn for the non-ferrous metals, paper and cellulose, steel products, fertilisers and chemical products, and $\$ 2.2$ bn for capital goods [Barros de Castro and Pires de Sousa 1985:58].
}

16,000 , while 15,000 tanker trucks, as well as railways, ships and an incipient pipeline system are used. The losses of Petrobras - the largest public enterprise in Brazil - arising out of subsidising retail prices for alcohol are very substantial indeed, but the company is prepared to go ahead, as a compensation for the monopolistic position it enjoys in oil production. ${ }^{3}$

Another important economic consideration that should not be lost sight of is the catastrophic fall in sugar prices on the world market. Without 'ProAlcool' the Brazilian sugar industry would be ruined by now or else would require large subsidies and rescue operations from the Government.

\section{Social Effects}

Let us look now at the social impact of 'Pro-Alcool'.

In 1984, 423,000 people were directly employed in activities related to 'Pro-Alcool', compared to under 200,000 in 1981 and 28,000 in 1975. Another $1.8 \mathrm{mn}$ jobs are credited to the programme in related industries. But these figures, found in official documents, appear to be overestimates (they do not take account of the fact that some 'new' jobs substituted for agricultural activities). Moreover, only a part of the 400,000 direct jobs created are permanent. About 70 per cent of the 320,000 jobs in sugar cane planting and harvesting are temporary and do not extend beyond six months per year [Homem de Melo and Pelin 1981]. Large-scale, mechanised sugarcane cultivation tends to expel rural workers from tiny subsistence plots, previously allotted to them in the estates. The workers are forced to migrate to the towns, while continuing to be employed as casual agricultural labourers. Several studies have shown how precarious are the living conditions of such labourers, known as 'boias frias'. ${ }^{4}$

Thus, less than one per cent of the economically active population is at present employed in the production of alcohol - about three quarters in the fields and one quarter in the distilleries. The average cost of each job works out at between $\$ 20,000$ and $\$ 50,000$ depending on the estimate of the investment outlays referred to above. The least one can say, contrary to official evaluations, is that 'Pro-Alcool' does not commend itself from the employment point of view. Ways of generating employment at a lesser cost must be found in a country where new entrants on the labour market number $1.5 \mathrm{mn}$ each year. It might well be that sugarcane and alcohol production on smaller farms and in small distilleries could provide more jobs with a lower capital/labour ratio, the necessary condition for such an alternative being effective land reform. ${ }^{5}$

${ }^{3}$ See the interview with the new President of Petrobras, Ozires Silva, Folha De Saô Paulo, 8 June, 1986.

'Literally, 'those who eat cold meals', as they are taken by truck from the town to the fields at dawn and brought back in the evening. 
The emphasis put on the production of sugar-cane, together with the priority accorded to exportable cash crops, has had a backlash effect on the production of staple food. Brazil's availability of cultivable land is so huge that, at first sight, there should be room for simultaneously expanding biomass fuels, cash crops and food. After all, only $9.39 \mathrm{mn}$ acres - of which almost half are in Saõ Paulo State, are taken up by sugar-cane plantations, out of a total of $112.2 \mathrm{mn}$ acres cultivated and $618 \mathrm{mn}$ acres of arable land (see Figures 1 and 2, 1984 data). But the competition between biomass fuels, exportables and staples does not arise at the level of cultivable land in general. It affects conveniently situated prime land and, above all, resources other than land (access to preferential credits, subsidies, etc).

The situation can be appreciated from Table 3 . Between 1977 and 1984 the production per capita of sugar-cane increased at an average annual rate of 7.84 per cent and exportables grew by more than 2.5 per cent, while the production of meat stagnated. At the same time, the output per capita of five staples decreased at an annual rate of -1.94 per cent. The adverse consequences for the living standards of the lower income strata of the population are easy to imagine with food prices appreciating more rapidly than incomes.

Finally, one should mention the impact of 'ProAlcool' on the concentration of land ownership and income. Virtually all the sugar-cane is produced on large estates, with an extremely uneven regional distribution pattern. In 1983-84 out of $189 \mathrm{mn}$ tons of sugar-cane produced in Brazil (about one quarter of world production) the relative share of the South Central region was 77 per cent. Sixty per cent of distilling capacity is concentrated in Saõ Paulo State alone, with Alagoas and Pernambuco - traditional sugar producing areas - ranking second and third with 7.9 and 5.6 per cent respectively of installed capacity.

\section{Ecological Impacts}

Sugar-cane moculture in large estates - an alcohol plant with a daily output of 120,000 litres requires about 6,000 hectares of plantation - does not allow for a rational pattern of land use from an ecological standpoint [see Borges et al. 1985], at least in some micro-regions. Even more serious is the problem of disposing of the highly polluting effluent from alcohol distillation: 12 to 13 gallons of stillage for each gallon of ethanol. Theoretically, it is possible to use this effluent directly as fertiliser (on some soils), to treat it in stabilisation ponds, to process it in bio-digesters and even to extract valuable feedstock from it. In

\footnotetext{
' A much discussed question in the 'Nova Republica'. President Sarney created high expectations by announcing a fairly radical land reform. Implementation is, however, lagging behind and prospects are not encouraging.
}

practice, means to enforce the environmental legislation are faulty, and occasionally the effluent finds its way to the nearest river, with devastating effects on the fauna and great losses for the riparian population depending on water supply from the river and on fishing for their livelihood.

By contrast, adding anhydrous ethanol to gasoline, instead of lead, to enhance the octane levels, reduces air pollution. Between 1978 and 1984 the concentration of lead in the atmosphere of Saõ Paulo city was reduced by 75 per cent according to studies conducted by CETESB (the state-controlled environment protection agency) [Maimon et al. 1980]. The same agency is yet to produce evidence on the controversial problem of the aldehydes released by ethanol-powered cars.

\section{'Pro-Alcool' or Pro-Biomass Fuel?}

Falling oil prices make further expansion of 'ProAlcool' unlikely in spite of efforts to the contrary by Copersugar. At least, the grandiose plans to reach 57 bn litres of alcohol output in the year $2000-30$ bn to substitute for gasoline and 27 bn to substitute for diesel oil - have been shelved. Further increases in domestic production of oil and gas are much more likely to be given priority in government plans.

Quite apart from its high production costs, 'ProAlcool' is open to criticism on a more fundamental ground. In its present form it serves to reinforce - or, perhaps, even to save from collapse - a development style and a consumption pattern based on growth through inequality, lopsided modernisation, income concentration and regional disparities, with the resulting hypertrophy of the sector producing 'luxuries' at the expense of 'essentials'. More than 30 per cent of urban households in Brazil own a car. When this datum is plotted against income distribution, the only possible conclusion, it would seem, is that the standard economic analysis of consumer behaviour has been stood on its head! Ownership of cars comes long before the basic necessities, including food, not to speak of housing, are satisfied. Given the symbolic value of the car and the leading role of the motor-car industry, the oil shock in 1973 could have developed into a drastic change in the direction hitherto followed by the country if the threat of fuel shortage had materialised.

In this perspective, 'Pro-Alcool' appears as a successful achievement of a 'war economy'. Gasoline had to be substituted for, whatever the economic, social or ecological costs, in order to prevent a change in lifestyles and the dethronment of the car. One can hardly find a better example of what Donald Schon calls 'conservative dynamism' (1971).

Thus a great opportunity to engage in a massive energy conservation programme and to restructure the transport system ${ }^{6}$ was missed. The country 
engaged, on the one hand in an ultimately successful (albeit unnecessarily costly) programme of import substituting heavy industrialisation [see Barros de Castro and Pires de Souza 1985]. On the other, it stepped up investment in gigantic hydroelectric projects and signed an over-ambitious nuclear agreement with the German Federal Republic (later discontinued after being subjected to a devastating criticism by the Brazilian scientific community). The response to the oil shock came mainly at the energy supply level. This means that the opportunities foregone 10 years ago are still there. Conservation of energy, restructuring the transport system, as well as a better integration of local and regional economies in order to eliminate unnecessary hauling of goods over long distances, should find their way into the next national development plan.

But there is room, equally, for developing alternative sources of energy, in particular biomass energy. It may be useful, in this respect, to recall the premisses on which 'Pro-Alcool' was initially predictated. The first idea was to produce ethanol from cassava, using marginal land for this purpose and providing employment and income to poor peasants. The social component was thus built into the concept and the competition for prime land avoided. The project proved infeasible. Agronomists did not know enough about cassava - the staple food par excellence of the poor and originally from Brazil - as the bulk of the

\footnotetext{
${ }^{6}$ No other large country in the world has such a high dependency ratio on road transportation - 96 per cent of passenger vehicles and 80 per cent of goods vehicles.
}

agricultural research effort had been allocated to exportables. The energy balance of the distillation process was negative in the absence of the bagasse used by distilleries working with sugar-cane. A bove all, the influential sugar lobby was preoccupied with the evolution of external markets and anxious to use the idle capacity of their distilleries. The social preoccupations of 'Pro-Alcool' were quickly forgotten. Instead, the authoritarian regime came to the rescue of sugar planters and millers.

The 'Nova Republica' could, however, go back to the initial assumptions of 'Pro-Alcool' and embrace them in a Pro-Biomass Fuel programme founded on the following principles:

- a country as huge and diversified as Brazil ought to explore not one but several biomass fuel options, best adapted to the specific conditions of each agroclimatic zone;

- the emphasis should be on local solutions, making the best use of the diversified resource base and identifying technologies most appropriate to the ecological, cultural and socioeconomic contexts; ${ }^{7}$

- the needs of the people - primarily the larger part of the Brazilian population who live below the poverty line - should always be given first priority;

- integrated food-energy systems should be preferred to the juxtaposition of single purpose endeavours in

\footnotetext{
A way of supporting local innovations might be to withdraw the subsidy to the transportation of fuels to distant regions on the condition of allocating the same amount of resources to subsidise the use of alternative energy sources.
}

\section{\begin{tabular}{|l|l|l|}
\hline Table 1 & Brazil: Fuel consumption (Otto cycle engines)
\end{tabular} (mn litres)}

\begin{tabular}{|ccccccc}
\hline Year & Gasoline & $\begin{array}{c}\text { Anhydrous } \\
\text { Alcohol }\end{array}$ & $\begin{array}{c}\text { Hydrated } \\
\text { Alcohol }\end{array}$ & $\begin{array}{c}\text { Fuel demand for Otto } \\
\text { cycle engines (in } \\
\text { gasoline equivalent) }\end{array}$ & $\begin{array}{c}\% \text { of anhydrous } \\
\text { alcohol in } \\
\text { gasoline }\end{array}$ & $\begin{array}{c}\text { Total } \\
\text { consumption } \\
\text { of alcohol }\end{array}$ \\
\hline 1978 & 13,846 & 1,506 & 2 & 15,354 & 9.8 & 1,508 \\
1979 & 13,534 & 2,219 & 16 & 15,766 & 14.1 & 2,235 \\
1980 & 11,534 & 2,253 & 429 & 14,130 & 16.3 & 2,682 \\
1981 & 11,036 & 1,146 & 1,392 & 13,295 & 9.4 & 2,538 \\
1982 & 10,502 & 2,021 & 1,674 & 13,862 & 16.1 & 3,695 \\
1983 & 8,782 & 2,197 & 2,950 & 13,338 & 20.5 & 5,147 \\
1984 & 7,778 & 2,001 & 4,468 & 13,352 & 20.5 & 6,469 \\
$* 1985$ & 7,249 & 2,084 & 5,542 & 13,765 & 22.0 & 7,626 \\
\hline
\end{tabular}

* Estimate

Source: Guarnieri and Nunes 1986 
order to meet the food-fuel complementarity in peoples' consumption and to explore positive foodfuel synergies at the production level;

- special attention should be given to the valorisation of agricultural wastes and their optimal allocation between five potential uses as fuel, fertiliser, animal food, industrial feedstock and, occasionally, food for human consumption.

The latter point is but one illustration of a much broader question. The pattern of resource use up to now has been extremely wasteful. This gives Brazil a unique opportunity to step up growth with little investment merely by eliminating wastefulness, and improving the maintenance of and use-intensity of the existing production apparatus. As far as biomass energy is concerned, the Agro-energy Communities Program, started on an experimental basis by FINEP (Agency for Financing Research and Development) in tandem with the Food-Energy Nexus Program of the United Nations University, constitutes a first effort to identify and test socially relevant, ecologically

\section{Figure 1}

\section{DISTRIBUTION OF \\ BRAZIL'S TERRITORY OF 2,103 MILLION ACRES}

\section{Figure 2}

\section{DISTRIBUTION OF}

THE CULTIVATED AREA BY CROPS

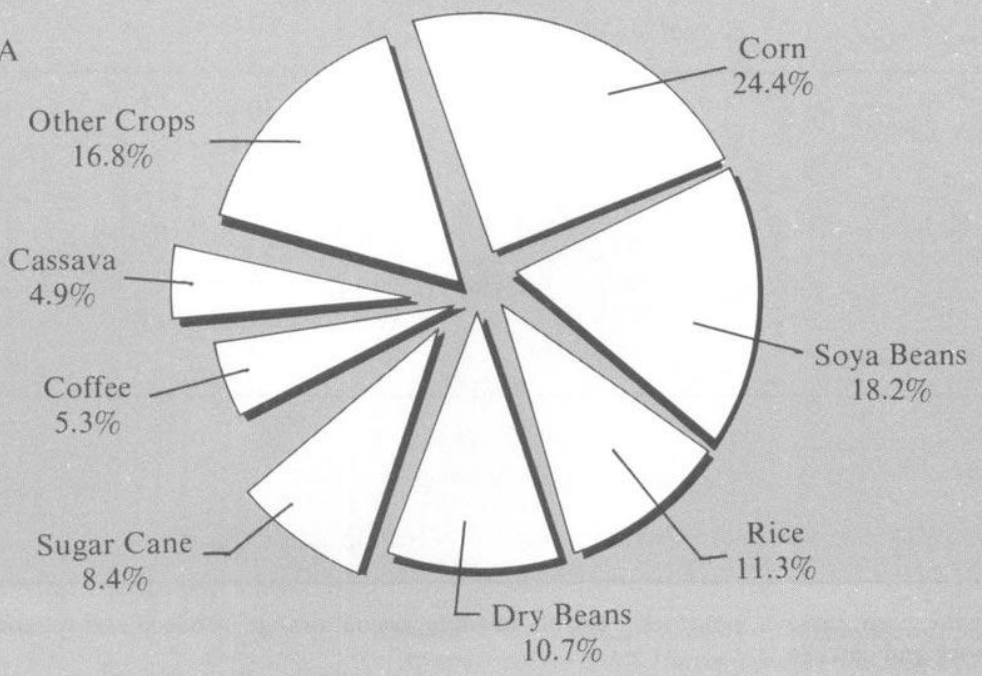


sustainable and economically viable solutions [La Rovere and Tolmasquim 1985].

The above remarks should not be interpreted as an invitation to renounce the objective of rationalisation

\begin{tabular}{|c|c|c|c|}
\hline Table 2 & \multicolumn{2}{|c|}{ Brazil: Sugar exports } & \\
\hline Year & 1,000 tonnes & US\$'000 & $\begin{array}{c}\text { Average price } \\
\text { per } \\
\text { US\$/tonne }\end{array}$ \\
\hline 1977 & $2,486.6$ & 234,000 & 94.1 \\
\hline 1978 & $1,924.6$ & 196,000 & 101.8 \\
\hline 1979 & $1,941.6$ & 247,000 & 127.2 \\
\hline 1980 & $2,661.9$ & 624,000 & 234.4 \\
\hline 1981 & $2,670.1$ & 579,000 & 216.8 \\
\hline 1982 & $2,788.2$ & 259,000 & 92.9 \\
\hline 1983 & $2,800.6$ & 320,000 & 114.3 \\
\hline 1984 & $3,039.5$ & 308,000 & 101.3 \\
\hline $1985^{*}$ & $1,428.7$ & 81,000 & 56.7 \\
\hline
\end{tabular}

* Estimate

Source: Guarnieri and Nunes 1986 in the use of existing distilling capacity by improving the productivity of the entire plantation cycle. 'ProAlcool' created an irreversible situation, whatever reservations one may have, ex-post, about the social and ecological costs of this programme.

\section{References}

Barros de Castro, A. and F. E. Pires de Sousa, 1985, 'A Economia Brasileira em Marcha Forçada', Paz e Terra, Rio de Janeiro

Barzelay, M. and S. R. Pearson, 1985, 'The efficiency of producing alcohol for energy in Brazil: a reply', Economic Development and Cultural Change, vol 33 no 4, pp857-61

Batista, I. S., 1984, 'Evoluçao das condiçoes de finaciamento do Proalcool', Iplan

Borges, U., H. Freitag, T. Hurtienne, M. Nitsch, 1985, 'Proalcool-Economia Politica e Avaliaçao socio-econômia do Programa brasileiro de bio-combustiveis', Instituto de Estudos Latinoamericanos, Universidade Livre de Berlim

Copersugar, 1985, 'International Symposium on Sugar and Alcohol', Saõ Paulo, 1985

Exame, 1985, 'A Ressaca do Proalcool', 27 November

Gazeta Mercantil, 1986, 'Mais Alcool Menos Açucar', 4 June

Table 3 Brazil: Indices of production per capita of staple foods, exportables, sugar-cane and meat

\begin{tabular}{|c|c|c|c|c|c|}
\hline Year & $\begin{array}{c}\text { Crops for } \\
\text { the internal } \\
\text { market }{ }^{1}\end{array}$ & \multicolumn{2}{|c|}{$\begin{array}{c}\text { Exportable } \\
\text { crops }\end{array}$} & Sugarcane & Meat $^{4}$ \\
\hline 1977 & 100.0 & 100.0 & 100.0 & 100.0 & 100.0 \\
\hline 1978 & 86.0 & 88.0 & 101.0 & 105.1 & 97.8 \\
\hline 1979 & 87.3 & 94.0 & 106.1 & 110.5 & 95.8 \\
\hline 1980 & 90.8 & 112.8 & 108.9 & 115.6 & 97.9 \\
\hline 1981 & 90.2 & 110.6 & 136.9 & 118.3 & 103.7 \\
\hline 1982 & 96.5 & 104.2 & 98.6 & 137.9 & 106.6 \\
\hline 1983 & 73.6 & 107.2 & 120.9 & 156.4 & 103.0 \\
\hline 1984 & 84.9 & 113.3 & 119.0 & 174.8 & 99.1 \\
\hline $\begin{array}{l}\text { Annual } \\
\text { average growth } \\
\text { rate }\end{array}$ & & & & & \\
\hline $1977 / 84(\%)$ & -1.94 & 2.56 & 2.53 & 7.84 & zero \\
\hline
\end{tabular}

${ }^{1}$ rice, beans, corn, cassava, pototoes; ${ }^{2}$ cotton, peanuts, cocoa, orange, tobacco and soyabeans; ${ }^{3}$ the same plus coffee;

${ }^{4}$ beef, pork and chicken

Source: Homem de Melo 1985 
Guarnieri, C. G. and E. R. F. Nunes, 1986, 'Alternativas de Demanda de Alcool com Relacao à Capacidade l nstalada', Conselho Estadual de Energie, Saõ Paulo

Homem de Melo, F., 1985, 'Prioridade Agricola: Sucesso ou Fracasso?' Fipe/Pioneira, Saõ Paulo

—and E. G. Pelin, 1981, 'Proalcool, Energia et Transportes', Fipe/Pioneira, Saõ Paulo

-1983, 'As soluçoes Energéticas e Economia Brasileira', Hucitec/Edusp, Saõ Paulo

La Rovere, E., and M. T. Tolmasquim, 1985, 'Integrated Food-Systems in Brazil', the UNU Food Energy Nexus Programme, Paris

\section{Books Received}

K. P. Padmanabhan, Rural Financial Intermediation, Shubhada-Saraswat Publications, Pune, 1986

Irene Norlund, Sven Cederroth and Ingela Gerdin, Rice Societies: Asian Problents and Prospecrs, Scandinavian Institute of Asian Studies/Curzon Press, London, 1986

Jan Knippers Black, The Dominican Republic: politics and development in an unsovereign state, Allen \& Unwin, London, 1986

Augustín Escobar Latapi, Con el Sudor de lu frente: Mercado de trabajo y' clase obrera en Guadalajara, El Colegio de Jalisco (Mexico), 1986

Guillermo de la Peña y Agustín Escobar (comps.), Cambio regional, mercado de rabajo y vida obrera en Jalisco, El Colegio de Jalisco (Mexico), 1986

Mohamed T. El-Ashry and Diana C. Gibbons, Troubled Waters: New policies for managing water in the American West, World Resources Institute, Washington, 1986

Joel Greer and Erik Thorbecke, Food Poverty and Consumption Parterns in Kenl'a, ILO, Geneva, 1986

Mesfin Wolde Mariam, Rural Vulnerability to Famine in Ethiopia - 1958-1977, Intermediate Technology Publications, London, 1986

The World Bank Annual Report 1986
Maimon, D. et al. 1980, 'Poluicao do Ar na Regiao Metropolitana do Rio de Janeiro e Saõ Paulo', SUPREN/1BGE (mimeo)

Sachs, 1., 1983, 'Le potentiel de développement endogène', Economie et Sociétés, Cahiers de l'lsmea, Paris, Serie F, no $29, T$. XVIl no 2

Senhor, 1986, 'O Proalcool', 4 March

Schon, D., 1981, Beyond the Stable State, W. W. Norton and Co, New York

Fred Bridgland, Jonas Savimbi: A Kel' 10 Africa, Mainstream Publishing Co., Edinburgh, 1986

International Television Trust for the Environment, Switching on to the Environment: a critical guide to films on env'ironment and development, Nottingham, 1986

Michael Ayre, The Design of Biclcle Trailers, Intermediate Technology Publications, London, 1986

John Norton, Building with Earth: A Handbook, Intermediate Technology Publications, London, 1986

Richard L. Kitchen, Finance for the Developing Countries, Wiley, Chichester, 1986

Kathryn M. Robinson, Stepchildren of Progress: the political economy of development in an Indonesian mining town, State University of New York Press, 1986

Towards Control of Deserification in African Drilands, Sonderpublikation der GTZ no. 168, Eschborn, 1986

South-North Dialogue in Korea, International Cultural Society of Korea, Seoul, 1986

Y. M. Yeung and T. G. McGee(eds.), Community Participation in Delivering Urban Services in Asia, IDRC, Ottawa, 1986

Richard W. Ryan, Teaching Comparative-Development Administration at US Universities: a collection and analy'sis of syllabi, Kumarian Press, West Hartford (Conn.), 1986 